\title{
Društva upokojencev kot pospeševalci turistične potrošnje in prostočasnih dejavnosti slovenskih upokojencev
}

\author{
Bojan Macuh* \\ Fakulteta za komercialne in poslovne vede Celje, Lava 7, 3000 Celje, Slovenija \\ bojan.macuh@guest.arnes.si
}

Andrej Raspor

Doba Fakulteta, Prešernova 1, 2000 Maribor,

Fakulteta za uporabne družbene študije,_Gregorčičeva 19, 5000 Nova Gorica, Slovenija andrej.raspor@ceatm.org

\begin{abstract}
Povzetek:
Raziskovalno vprašanje: Kako pogosto in s kakšnimi motivi se upokojenci poslužujejo turističnih ponudb v okviru organiziranih prostočasnih aktivnosti društev upokojencev?

Namen: Ugotoviti želimo, kako so organizirane prostočasne dejavnosti in ali je dovolj turističnih ponudb za upokojence glede na njihovo finančno stanje in ovire, s katerimi se soočajo.

Metode: Raziskave smo izvajali med slovenskimi društvi upokojencev. Izvedli smo spletno anketo v obdobju med 15. aprilom in 15. julijem 2018. Da bi povečali odzivnost, saj je bila ta v prvi fazi zelo slaba, smo spletno anketo $\mathrm{v}$ istem obdobju dopolnili s telefonskim anketiranjem, ki so ga izvajali študenti FUDŠ.

Rezultati: Društva upokojencev imajo organiziranih veliko prostočasnih dejavnosti. Pri turističnih potovanjih se bolj nagibajo k dnevnim izletom po Slovenji. Zaradi omejenih financ je pri odločitvi za izbiro gostinskega obrata pomembna cena namestitve, veliko manj pa je upokojence zanimalo, kakšna je klasifikacija namestitve.

Organizacija: Ugotovitve raziskave so relevantne za turistične organizacije in društva upokojencev. Tako lahko turistične organizacije prilagodijo turistično ponudbo. Društva upokojencev se pri organizaciji prostočasnih dejavnosti lahko povežejo in optimizirajo delo.

Družba: Prispevek je pomemben z vidika starajoče se družbe. Delež starejših oseb se namreč povečuje in bo potrebno ustrezno poskrbeti tudi za njihove prostočasne aktivnosti, kamor sodijo tudi turistične dejavnosti.

Originalnost: Gre za prvo tako celovito raziskavo, ki je bila izvedena med društvi upokojencev v Sloveniji in je iskala odgovore glede organizacije turističnih potovanj ter motivov upokojencev za udeležbo.

Omejitve raziskave/nadaljnje raziskave: Omejitev raziskave se kaže v tem, da so bili vključeni le vodje društev upokojencev. Za celovito mnenje bi morali izvesti fokusne skupine v nekaj izbranih društvih upokojencev in po mnenju povprašati tudi člane neposredno. Raziskava tudi ne pokriva upokojencev, ki niso aktivni v društvih.
\end{abstract}

Ključne besede: Slovenja, upokojenci, turizem, destinacija, izleti, ponudba. 


\section{Uvod}

Danes potujejo vsi, v potovanja pa se vključuje tudi vse več starejših, kar v preteklosti ni bil množičen pojav. Ena najpogostejših trditev o starejših potnikih je ta, da so ti danes drugačni od prejšnjih generacij in bodo tudi v prihodnje drugačni od današnjih. Boljše kot je zdravje in višji kot je življenjski standard, dejavnejši in bogatejši so starejši.

Starejši imajo danes na splošno višje prihodke kot pretekle generacije, zato bodo več denarja vlagali v prostočasne dejavnosti, s čimer se bo delež starejših v turizmu le večal. Eden najbolj jasnih demografskih trendov na svetu je staranje prebivalstva, predvsem v razvitih državah. Sodobni družbeni pojav je vzbudil precejšnje zanimanje na vseh področjih. Oblikovale so se številne napovedi glede vpliva tega trenda na različne sektorje, vključno s turizmom. Po drugi strani pa se je starost pokazala kot pomemben dejavnik človeškega vedenja in ekonomskega povpraševanja. Globoke demografske spremembe, kot je trend staranja in prevlada velike generacije »baby boom«, globalno vplivajo tako na turizem kot na prostočasno in potovalno industrijo ter na ostale sektorje v družbi. Dejavnejše udejstvovanje v prostem času, pogostejša potovanja in spremenjene potrebe starejših spodbujajo razvoj novih proizvodov (Weiermair \& Mathies, 2004, str. 29).

$\mathrm{Na}$ globalni ravni so se proti koncu 20. stoletja in pospešeno po letu 2000 na staranje prebivalstva in $\mathrm{z}$ njim povezane demografske probleme odzvala politika s pomembnimi mednarodnimi dokumenti ter posamezne znanosti $\mathrm{z}$ raziskovanjem, publiciranjem in razvijanjem novih modelov za ravnanje (Ramovš, 2014. str. 6). Starejše je treba spodbujati, da čim dlje ostanejo aktivni na številnih področjih. Možne dejavnosti niso vedno povezane le z zaposlitvijo in družinskim življenjem, dobrodošlo je tudi vključevanje v različne družbene aktivnosti, ki preprečujejo osamljenost in izolacijo.

V okviru raziskave smo želeli odgovoriti na raziskovalno vprašanje, kako pogosto in s kakšnimi motivi se upokojenci poslužujejo turističnih ponudb v okviru organiziranih prostočasnih aktivnosti društev upokojencev?

Raziskava je razdeljena na teoretični, raziskovalni del in na del, kjer odgovorimo na zgornje raziskovalno vprašanje.

\section{Teoretična izhodišča}

Starostno obdobje, sklicujoč se ne definicijo Beera, danes delimo na več faz, ki jih tudi poimenujemo glede na pričakovano vitalnost ljudi v posamezni kategoriji, in sicer: od 65 let do 74 let (mlajši starejši), od 75 do 84 let (srednje starejši) ter 85 let in več (stari starejši). Na kratko bomo omenili še nekaj socialno-ekonomskih in kulturnih dejavnikov demografskih procesov, ti so: 
- izobrazba: bolj izobraženi ljudje v povprečju živijo bolj zdravo od ostalih. Izobražene ženske v povprečju rodijo manj otrok, poleg tega pa zasedajo v službah višje položaje in težje usklajujejo kariero in družinsko življenje;

- gospodarstvo: visok BDP pomeni visok prihodek in posledično večje zaupanje v gospodarstvo in višjo stopnjo rodnosti. Obenem pa se izboljšuje zdravstveni sistem, podjetja izboljšujejo pogoje dela;

- zdravstvo: boljše življenjske razmere in zdravstvena oskrba vodijo v višje življenjsko pričakovanje;

- tehnologija: nove zdravstvene tehnike omogočajo neplodnim ženskam možnost oploditve in s tem višjo stopnjo totalne rodnosti (Beer, 2013, str. 75-89).

\subsection{Mobilnost in turistična potovanja}

Tako kot mobilnost mladih pripomore k njihovi splošni sposobnosti prilagajanja, natančneje, $\mathrm{k}$ njihovi lažji (re)integraciji na (nad)nacionalni trg dela (Lavrič in Godina, 2011, str. 379), mobilnost posameznikom omogoča, da pridobijo znanje in veščine, ki jih danes od njih zahteva svetovno gospodarstvo oziroma svetovni trg dela: znanje tujih jezikov, odprtost, strpnost do drugačnosti, pripravljenost na medkulturni dialog in sposobnost čezmejnega sodelovanja, zato so tudi mobilni študenti po končanem študiju pogosteje zasedali bolje plačana delovna mesta, se pogosteje prijavljali na delovna mesta $\mathrm{v}$ tujini in svojo kariero pogosteje videli $\mathrm{v}$ mednarodnem okolju. Resda starejše osebe, še posebej tiste, ki so že v domovih za starejše, nimajo potreb po novem delu, lahko pa se v mobilnost drugače vključujejo in izkoristijo to izkušnjo. Izkušnja mobilnosti vpliva, da je posameznik bolj samostojen, razumevajoč in strpen do drugačnih (ibidem, str. 379). Po podatkih Svetovne turistične organizacije (Dann, 2001, str. 235-238) so bili napovedani trendi na področju turizma do leta $2020 \mathrm{v}$ smer: povečanja števila starejših turistov, spremembe od aktivnih počitnic na počitnice, ki temeljijo na izkušnjah, in vedno bolj kompleksne segmentacije povpraševanja $\mathrm{v}$ skladu z različnimi cilji ali nameni tradicionalnega potovanja (npr. destinacije, medeni tedni z dostopom do sonca in plaže, kulturni ali križarski izdelki). To se je v celoti realiziralo. Starejšim je omogočena različna specializirana ponudba. Ena izmed oblik je tudi dopustovanje v specializiranih hotelih ali izmenjave postelje v domovih prek portalov. Seniorski turizem ima velik potencial. Potovanje je za vse ljudi način preživljanja prostega časa. Pri tem ljudje vseh generacij uživajo. Še posebej upokojenci imajo več prostega časa za potovanja. Kljub omenjenemu dejstvu je v turistični statistiki Eurostata $\mathrm{v}$ letu 2013 v turizmu sodelovalo le nekaj manj kot polovica (47,1 \%) prebivalcev EU, starih 65 let in več, medtem ko so prebivalci, stari 15 let in več, sodelovali v 60,0 \% deležu (Population and social conditions - Statistics Explained, 2017). Kot pri drugih starostnih skupinah so možnosti za potovanja in turizem $\mathrm{v}$ starejših letih ravno tako povezane $\mathrm{z}$ razpoložljivostjo dohodka (finančni razlogi). Vendar pa je med starejšimi še posebej pomembno vprašanje pričakovane življenjske dobe: želja starih ljudi po potovanjih se s starostjo resnično zmanjšuje. Vprašanja v zvezi z zdravjem so pri ugotavljanju, ali je starejše prebivalstvo EU sodelovalo v turizmu ali ne, imela nekoliko večjo vlogo kot finančna vprašanja, relativno visok delež starejših pa ni imel motivacije za potovanje/odhod na počitnice (Europe Senior Tourism, 2017). 


\subsection{Upokojenci}

Naslednja pomembna definicija za našo raziskavo je kdo je upokojenec? Upokojênec tudi upokójenec je, kdor je upokojen; družinski upokojenec je, kdor dobiva pokojnino kot član družine umrlega zavarovanca ali upokojenca; osebni upokojenec dobiva pokojnino iz lastnega zavarovanja; starostni upokojenec dobiva pokojnino iz lastnega zavarovanja po izpolnitvi določene starosti in delovne dobe (Gliha Komac, 2017). Upokojenec je torej oseba, ki je dopolnila zakonsko število let delovne dobe v odnosu do starostne dobe, ki mora biti izpolnjena kot pogoj za upokojitev. Podobno kot večina držav zahodnega sveta se tudi Republika Slovenija sooča s spremembami na demografskem področju (Dobrina, 2017, str. 8-9), ki že vplivajo oziroma bodo $\mathrm{v}$ prihodnosti pomembno vplivale na vsa področja življenja (zaposlovanje, obremenitev javnega zdravstva, produktivnost gospodarstva ipd.) (Thompson, 2016), med drugim tudi na zdravstveno stanje prebivalstva. Analiza podatkov o uporabi zdravstvenih storitev starejšega prebivalstva v Sloveniji (raziskava SHARE) je potrdila, da starejši posamezniki pogosteje poiščejo ambulantno oskrbo, jemljejo več zdravil in so v večjem deležu hospitalizirani. Izjema so najstarejši starostniki (stari 85 let ali več), pri katerih je uporaba zdravstvenih storitev manjša kot pri starostni skupini od 70 do 79 let (Hren, Prevolnik Rupel in Srakar, 2015, str. 75-82). V obdobju od leta 1900 do leta 2000 se je v večini držav razvitega sveta povprečna starost povečala za skoraj 30 let. Obenem pa se je na drugi strani konstantno zmanjševalo število rojstev, zato se je v vseh državah število starejšega prebivalstva neprestano večalo, kar velja še danes (Dobrina, 2017, str. 8). Posledica staranja prebivalstva je tudi večje število upokojencev, ki prav tako narašča, vendar je treba poudariti, da rast števila upokojencev ni bila vedno pogojena samo s staranjem prebivalstva. Tako kot mnoge druge države je tudi Slovenija v preteklosti reševala težave na trgu dela z zgodnjim upokojevanjem delovne sile, ki bi bila ob ugodnejših gospodarskih razmerah še vedno delovno aktivna (zaradi propada velikega števila podjetij po osamosvojitvi Slovenije se je visoko brezposelnost reševalo tudi z zgodnejšim upokojevanjem) (Dobrina, 2017, str. 14). Za delovno aktivno prebivalstvo v Sloveniji je značilno, da se v veliki večini primerov ljudje upokojijo takoj, ko izpolnijo prvi pogoj za starostno upokojitev in pridobijo pravico do starostne pokojnine brez odbitkov. Več kot $70 \%$ upokojencev se je tako upokojilo, ker so izpolnili pogoje za starostno pokojnino, skoraj $15 \%$ upokojencev pa je izbralo možnost predčasne upokojitve. Delež upokojencev, ki so se upokojili zaradi zdravstvenih razlogov, je 11,53 \% (Börsch-Supan, 2018). Omeniti je treba tudi izredno visok delež novih upokojencev, ki se starostno upokojijo po prenehanju prejemanja denarnega nadomestila za primer brezposelnosti ali plačila prispevkov za pokojninsko in invalidsko zavarovanje pri Zavodu RS za zaposlovanje - v zadnjih štirih letih je bilo takih skoraj tretjina vseh upokojitev v posameznem letu ali celo več. Delodajalci in delojemalci velikokrat izkoristijo zakonsko določeno možnost čakanja na upokojitev na Zavodu RS za zaposlovanje. Dobra informiranost zavarovancev o možnosti, kdaj se lahko starostno upokojijo in kakšno pokojnino bodo približno prejemali, izhaja tudi iz podatka o številu izdanih informativnih izračunov, ki jih izda Zavod za pokojninsko in invalidsko zavarovanje Slovenije vsako leto (preko 100.000 izračunov). Rast števila upokojencev se je zaradi zadnje reforme obveznega pokojninskega in invalidskega zavarovanja (v veljavi do 1. 1. 2013 dalje) precej 
zmanjšala, saj je bila v letu 2016 najnižja v zadnjih 20 letih ( 0,8 \% v primerjavi z letom 2015), samo razmerje med upokojenci in delovno aktivnimi prebivalci pa je še vedno nizko, in sicer 1,45 \% zaposlenega na enega upokojenca v letu 2016 (Zavod za pokojninsko in invalidsko zavarovanje Slovenije, 2017).

Glede na ugotovljeno lahko zaključimo, da imajo glede na relativno nizko starost ob upokojitvi slovenski upokojenci velik potencial, da se bodo udeleževali turističnih potovanja in drugih prostočasnih dejavnosti. Ovira je le relativno nizka pokojnina. Tako je znašala novembra 2019 najnižja pokojninska osnova (po ZPIZ-2 36. člen ZPIZ-2) 858,46 EUR, najvišja pa 3.433,84 EUR. Dejansko izplačana starostna pokojnina, odmerjena od najnižje pokojninske osnove (ZPIZ-2 za 40 let pokojninske dobe), je za moške znašala 491,47 EUR in ženske 545,12 EUR. Povprečna neto za (ZPIZ-2 za 40 let pokojninske dobe) je za moške znašala 659,33 EUR, za ženske pa 653,80 EUR (Zavod za pokojninsko in invalidsko zavarovanje Slovenije, 2019).

\subsection{Upokojenci in turizem}

Seniorji, starejši občani, tretja, srebrna ali siva generacija, zlata leta, upokojenci ali zgolj starejši je le nekaj izrazov, ki se uporabljajo, ko v potovalni in turistični industriji govorimo o ciljni skupini starejših (Krašovec, 2003, str. 27). So pomembna skupina turistov in predstavljajo t. i. baby boom generacijo, ki je že upokojena oziroma prihaja v leta upokojitve. Starejši so danes $\mathrm{v}$ boljšem zdravstvenem stanju kot v preteklosti, imajo višje prihodke, več časa za potovanja in visoko tendenco po potovanjih na daljše razdalje (Litrell, Paige in Sung, 2004, str. 349-350). Prav zaradi daljšanja življenjske dobe in boljšega zdravja se število starejših turistov povečuje. Spremenile so se tudi vrednote in življenjski slog starejših, saj si mnogi želijo v starosti še veliko doživeti, si okrepiti zdravje in se družbeno udejstvovati (Pogačnik, Leskovec, Cigale, Prosen, \& Laharnar, 2008, str. 27-38). Mnogi starejši ravno po upokojitvi menijo, da je prišel čas, da naredijo nekaj zase, in mnogi se prav takrat intenzivno udeležujejo izletov in najrazličnejših potovanj. Zato ni presenetljivo mnenje turističnih strokovnjakov, da je ciljna skupina starejših v turizmu celo najpomembnejša (Raspor idr., 2018, str. 20-23). Še pomembnejši je podatek, da so starejši v večini bolj izobraženi (tudi izkustveno, ne zgolj formalno) in pričakujejo od destinacije več kot »povprečni turisti«, vse življenje si želijo novih doživetij in novih spoznanj (Avcikurt, 2009, str. 154).

\subsection{Oskrba upokojencev in vloga društev upokojencev pri socializaciji le-teh}

Domača oskrba starejšega človeka ali osebe s posebnimi potrebami je zahtevno delo. V domovih za starejše skrbijo za oskrbovance osebe, ki so za oskrbo in nego starejših strokovno usposobljene in je to delo njihova poklicna izbira. Pri starejših ljudeh in pri osebah s posebnimi potrebami, ki živijo doma, vso potrebno oskrbo opravijo domači oskrbovalci ob svojem rednem delu. To delo jih izčrpava in večinoma ne dobijo od nikogar nobenega poduka, kako ostarelega in / ali osebo s posebnimi potrebami oskrbovati in negovati. Oskrbovanje bližnjega na domu na človeka vpliva telesno, čustveno, razumsko, duhovno pa tudi finančno. Domači oskrbovalec občuti napor in doživlja nemoč, stisko in pomanjkanje časa za vse svoje druge obveznosti in 
interese. Zaradi nezadostne pomoči in znanja so preobremenjeni, kar vodi v njihovo izgorelost. Pomagati jim je možno s kakovostnimi programi, v katerih se jih opolnomoči z znanji o domači oskrbi in z dobrimi izkušnjami drugih domačih oskrbovalcev v podobnih situacijah. Če upoštevamo, da velika večina ljudi želi živeti do konca življenja doma, kjer jim je vse najbolj znano in domače, potem sta izobraževanje in osveščanje edina smiselna pomoč na poti opolnomočenja domačih oskrbovalcev (ZiSS, 2017).

Društva upokojencev igrajo pomembno vlogo pri socializaciji upokojencev, še toliko bolj tistih, ki niso v okviru ustanov in so dovolj mobilni. Človek namreč nenehno niha med osebno intimnostjo in koristno vpetostjo v socialne mreže. Pri tem je tesno sožitje v mikrosocialnih skupinah vezni člen med obema poloma in združuje kakovosti obeh (Ramovš, 2003, str. 104200). Nove socialne mreže za sožitje generacij in kakovostno staranje zajemajo osebno svobodo in človekovo samostojnost. Gre za docela zavestno odločitev za medgeneracijsko prijateljevanje in sodelovanje, kjer veščine medgeneracijskega komuniciranja slonijo na principih socialnega učenja (Goriup, 2014, str. 92), saj se v društvih srečujejo starejši ljudje različnih generacij. Društva upokojencev in tudi sama Zveza društev upokojencev sta zunanja gerontološka dejavnost, ki skrbi za kakovostno življenje starejših ljudi, medgeneracijsko sožitje in ohranjanje medsebojne skupnosti (Malnar, 2015, str. 14). Hojnik Zupanc društvo upokojencev uvršča v samoiniciativno skupino civilne družbe (Hojnik-Zupanc in Mlinar, 1999, str. 137) in ima kot taka velik vpliv fizično in mentalno kondicijo starejših ljudi. Poleg tega pa je tudi mnenjski voditelj in usmerjevalec njihovega obnašanja in potrošnje, tudi $v$ okviru prostočasnih dejavnosti in turističnih potovanj.

\section{Metodologija}

V okviru raziskave, ki smo jo izvajali med slovenskimi društvi upokojencev, smo izvedli spletno anketo v obdobju med 15. aprilom in 15. julijem 2018. Da bi povečali odzivnost, saj je bila ta $\mathrm{v}$ prvi fazi zelo slaba, smo spletno anketo $\mathrm{v}$ istem obdobju dopolnili s telefonskim anketiranjem, ki so ga izvajali študenti FUDŠ.

Podatke za potrebe naše raziskave smo zbirali s pomočjo enotnega anketnega vprašalnika, zapisanega v Wordovem dokumentu, ki so ga društva upokojencev prejela na njihove spletne naslove. $V$ nadaljevanju navajamo le tista vprašanja, ki so relevantna za ta znanstveni prispevek (zaradi omejenega obsega ne predstavljamo vseh zaključkov). Vključeval je demografske podatke (število članov, povprečna starost, regija), drugi sklop vprašanj se je nanašal na dejavnosti društev (izobraževalne, kulturne, športne, izletniške aktivnosti), zadnji, tretji sklop vprašanj pa se je nanašal na sam predmet raziskave ciljne skupine dostopnega turizma (ponudba dostopnega turizma). Anketiranci so imeli na koncu anketnega vprašalnika možnost podati tudi odprte opisne odgovore. Prav ti odgovori nam bodo zelo koristili pri kreiranju bodočih tovrstnih raziskav.

V raziskavo smo vključili društva upokojencev iz baze Bizzi, za katere smo lahko pridobili elektronske naslove. Vseh skupaj je bilo 590. Glede na to, da se vsi niso odzvali, je raziskovalni vzorec zajel 273 društev upokojencev iz različnih regij po Sloveniji. 
Najprej predstavljamo demografske podatke za društva upokojencev (Tabela 1), med katerimi smo izvajali raziskavo. V Sloveniji je, kot smo že omenili, teh društev 590. Raziskavo smo izvedli med 273 društvi. Naš vzorec pokriva 46,3 \% populacije. Če pa upoštevamo zgolj tista društva, ki so bila pripravljena sodelovati in so torej izpolnila anketo, pa dobimo 228 društev, kar je 83 \% vseh društev, med katerimi smo izvedli raziskavo. Sicer pa se jih 10,3\% ni odzvalo, $5,5 \%$ jih ni želelo sodelovati, $0,7 \%$ pa je sodelovanje odklonilo, ker so imeli v teku neko drugo dejavnost.

Tabela 1. Pripravljenost na sodelovanje

\begin{tabular}{|c|c|c|c|c|}
\hline & \multicolumn{2}{|c|}{ So se odzvali na raziskavo } & \multicolumn{2}{|c|}{ Veljavni odgovori } \\
\hline & Število & Delež & Število & Veljaven delež \\
\hline Izpolnili anketo & 228 & $83,5 \%$ & 228 & $100 \%$ \\
\hline Ne želijo sodelovati & 15 & $5,5 \%$ & & \\
\hline Se niso odzvali & 28 & $10,3 \%$ & & \\
\hline Druga dejavnost & 2 & $0,7 \%$ & & \\
\hline Skupaj & 273 & $100 \%$ & 243 & $100 \%$ \\
\hline
\end{tabular}

V tabeli

Tabela 2. Distribucija glede na regijoje predstavljena distribucija glede na regijo. Zastopane so vse regije. Tudi distribucija je glede na posamezno razvitost in število društev invalidov v regiji primerljiva. Najbolj sta zastopani osrednjeslovenska regija $(21,6 \%$ vseh vključenih podjetij iz vzorca), sledi podravska (19,4 \%) in savinjska (16,5 \%). Sledijo še jugovzhodna Slovenija (7,3 $\%)$, gorenjska $(6,6 \%)$, goriška $(6,2 \%)$, pomurska $(5,9 \%)$ in obalno-kraška regija $(5,1 \%)$. Najmanj pa so zastopane posavska $(4,0 \%)$, koroška $(3,7 \%)$ in zasavska ter primorskonotranjska regija (obe po $1,8 \%$ ).

Tabela 2. Distribucija glede na regijo

\begin{tabular}{l|rrrr}
\hline & \multicolumn{3}{|c}{ POPULACIJA } & \multicolumn{2}{c}{ VZOREC } \\
\hline & Stevilo & \multicolumn{1}{c}{ Delež } & \multicolumn{1}{c}{ Stevilo } & \multicolumn{1}{c}{ Delež } \\
\hline Pomurska regija & 41 & $6,9 \%$ & 16 & $5,9 \%$ \\
Podravska regija & 118 & $20,0 \%$ & 53 & $19,4 \%$ \\
Koroška regija & 19 & $3,2 \%$ & 10 & $3,7 \%$ \\
Savinjska regija & 99 & $16,8 \%$ & 45 & $16,5 \%$ \\
Zasavska regija & 13 & $2,2 \%$ & 5 & $1,8 \%$ \\
Posavska regija & 18 & $3,1 \%$ & 11 & $4,0 \%$ \\
Jugovzhodna Slovenija & 44 & $7,5 \%$ & 20 & $7,3 \%$ \\
Osrednjeslovenska regija & 118 & $20,0 \%$ & 59 & $21,6 \%$ \\
Gorenjska regija & 44 & $7,5 \%$ & 18 & $6,6 \%$ \\
Primorsko-notranjska regija & 9 & $1,5 \%$ & 5 & $1,8 \%$ \\
Goriška regija & 39 & $6,6 \%$ & 17 & $6,2 \%$ \\
Obalno-kraška regija & 28 & $4,7 \%$ & 14 & $5,1 \%$ \\
\hline Skupaj & 590 & $100 \%$ & 273 & $100 \%$ \\
\hline
\end{tabular}

V tabeli 3 je prikazana povprečna starost članov društva. Kar 36,4 \%, torej več kot tretjina vseh anketiranih društev, je navedlo povprečno starost 75 let (18,4 \%) ali pa 70 let (14,1\%). Sledita jima skupini društev, ki so vpisali povprečno starost 76 in 78 let (obe skupini po 9,2\%). Najmanj društev je navedlo starost 69 let $(0,9 \%), 60$ let $(0,8 \%)$ in 73 let $(0,4 \%)$, okoli katere 
se sicer nahaja tudi izračunano povprečje - 73,4 let. Zaključimo lahko, da je povprečna starost članov slovenskih društev relativno nizka, in da se bo v prihodnih letih samo še dvigovala.

Tabela 3. Distribucija glede na povprečno starost

\begin{tabular}{r|rr}
\hline Navedena starost & Število društev & \multicolumn{1}{c}{ Dele ̌̆ } \\
\hline 60 & 2 & $0,8 \%$ \\
65 & 7 & $3,1 \%$ \\
67 & 7 & $3,1 \%$ \\
68 & 8 & $2,9 \%$ \\
69 & 2 & $0,9 \%$ \\
70 & 41 & $18 \%$ \\
71 & 4 & $1,8 \%$ \\
72 & 19 & $3,1 \%$ \\
73 & 13 & $0,4 \%$ \\
74 & 17 & $6,2 \%$ \\
75 & 42 & $18,4 \%$ \\
76 & 21 & $9,2 \%$ \\
77 & 6 & $2,2 \%$ \\
76 & 21 & $9,2 \%$ \\
79 & 6 & $2,6 \%$ \\
80 & 12 & $5,3 \%$ \\
\hline Skupaj & 228 & $100 \%$ \\
Povprečje & 73,4 let & \\
\hline
\end{tabular}

\section{Rezultati in razprava}

$\mathrm{V}$ tabeli 4 je predstavljena distribucija društev upokojencev glede na vrsto prostočasnih dejavnosti, ki jih izvajajo. Na razpolago so imeli 32 različnih možnosti, izmed katerih je največji delež odpadel na izlete, potovanja, oglede muzejev in znamenitosti, ki jih najdemo pod zaporedno številko 6 (7,4 \% ali v $94 \%$ društev). Na drugem mestu najdemo praznovanja, ki se nahajajo pod zaporedno številko $12(6,5 \%)$. Za njima tesno sledijo zaporedna številka 24 , kjer so navedeni balinanje, bowling, pikado in metanje $\mathrm{v}$ tarčo $(5,9 \%)$, druženje in pogovorna skupina pod številko $2(5,7 \%)$, športna in kulturna tekmovanja pod številko $28(5,5 \%)$ in skupine za samopomoč pod številko 11 (5,1\%). Najmanj pogosto organizirane dejavnosti so lokostrelstvo in zgodovinski krožek pod številkama 27 in 19 (obe po 0,7\%), gledanje televizije pod številko $3(0,6 \%)$, verske dejavnosti s številko $4(0,5 \%)$, terapija z gongi oz. glasbo s številko $30(0,2 \%)$, najmanj izvajana dejavnost med društvi upokojencev v raziskavi pa je terapija z živalmi pod številko 13 ( $0,1 \%$ ali samo v treh društvih upokojencev). 
Tabela 4. Distribucija glede na izvajane prostočasne dejavnosti

\begin{tabular}{|c|c|c|c|}
\hline Prostočasna dejavnost & $\begin{array}{r}\text { Imajo } \\
\text { organizirane } \\
\text { aktivnosti } \\
\end{array}$ & Delež & $\begin{array}{r}\text { Delež } \\
\text { med } \\
\text { vsemi }\end{array}$ \\
\hline 6 Izleti, potovanja, ogledi muzejev in znamenitosti & 213 & $7,40 \%$ & $94 \%$ \\
\hline 5 Sprehodi, tek, kolesarjenje, nordijska hoja & 192 & $6,80 \%$ & $85 \%$ \\
\hline $\begin{array}{l}12 \text { Praznovanja (verski, državni, občinski, mednarodni dnevi, šege in } \\
\text { običaji, rojstni dnevi), pikniki }\end{array}$ & 186 & $6,50 \%$ & $82 \%$ \\
\hline 24 Balinanje, bowling, pikado, metanje v tarčo & 169 & $5,90 \%$ & $74 \%$ \\
\hline 2 Druženje, pogovorna skupina & 165 & $5,70 \%$ & $73 \%$ \\
\hline 29 Tekmovanja (športna, kulturna ...) & 157 & $5,50 \%$ & $69 \%$ \\
\hline 11 Skupine za samopomoč & 146 & $5,10 \%$ & $64 \%$ \\
\hline 22 Predavanja (potopisna, strokovna) & 141 & $5,00 \%$ & $62 \%$ \\
\hline 9 Telovadba, joga, joga smeha, dihalne vaje & 139 & $4,80 \%$ & $61 \%$ \\
\hline 17 Likovna, ročna dela, rokodelske delavnice & 137 & $4,80 \%$ & $60 \%$ \\
\hline 16 Družabne igre, šah/šahovski turnirji & 125 & $4,30 \%$ & $55 \%$ \\
\hline $\begin{array}{l}21 \text { Medgeneracijski center (povezovanje tradicionalnih znanj, prenos } \\
\text { znanj na mlajše generacije) }\end{array}$ & 124 & $4,30 \%$ & $55 \%$ \\
\hline 8 Pevski zbor, glasbena sekcija & 118 & $4,10 \%$ & $52 \%$ \\
\hline 18 Vezenje, pletenje & 101 & $3,50 \%$ & $44 \%$ \\
\hline 26 Izdelava glasila (časopisi, revije, spletna stran) & 83 & $2,90 \%$ & $37 \%$ \\
\hline 23 Tečaj jezikov (nemščine, angleščine, italijanščine, ostalo) & 76 & $2,60 \%$ & $33 \%$ \\
\hline 15 Tombola, kviz, vaje za spomin, nagradne uganke, križanke, soduku & 70 & $2,40 \%$ & $31 \%$ \\
\hline 32 Vadba za pokretne, vaje za ravnotežje & 68 & $2,40 \%$ & $30 \%$ \\
\hline 1 Branje, literarni krožek & 66 & $2,30 \%$ & $29 \%$ \\
\hline $\begin{array}{l}7 \text { Vrtnarjenje, urejanje okolice in spoznavanje zelišč (uporaba, } \\
\text { gojenje) }\end{array}$ & 66 & $2,30 \%$ & $29 \%$ \\
\hline 20 Kognitivni (mentalni) trening ... & 54 & $1,90 \%$ & $24 \%$ \\
\hline 14 Plesna ustvarjalnica & 49 & $1,70 \%$ & $22 \%$ \\
\hline 10 Gospodinjski in slaščičarski krožek & 45 & $1,60 \%$ & $20 \%$ \\
\hline 31 Urjenje senzorike in motorike & 38 & $1,30 \%$ & $17 \%$ \\
\hline 25 Gledališka skupina (sodelovanje pri gledaliških igrah) & 36 & $1,30 \%$ & $16 \%$ \\
\hline 27 Košarka, nogomet, odbojka + ostale igre z žogo & 33 & $1,10 \%$ & $15 \%$ \\
\hline 19 Zgodovinski krožek & 21 & $0,70 \%$ & $9 \%$ \\
\hline 28 Lokostrelstvo & 21 & $0,70 \%$ & $9 \%$ \\
\hline 3 Gledanje televizije/ filmoteka & 16 & $0,60 \%$ & $7 \%$ \\
\hline 4 Verske dejavnosti & 13 & $0,50 \%$ & $6 \%$ \\
\hline 30 Terapija z gongi, terapija z glasbo (muzikoterapija) & 5 & $0,20 \%$ & $2 \%$ \\
\hline 13 Terapija z živalmi & 3 & $0,10 \%$ & $1 \%$ \\
\hline SKUPAJ & 2.876 & $100 \%$ & $100 \%$ \\
\hline
\end{tabular}

Iz navedenega lahko zaključimo, da imajo slovenska društva upokojencev zelo razvite prostočasne dejavnosti, ki se jih njihovi člani tudi poslužujejo.

V tabeli 5 je predstavljena distribucija društev upokojencev glede na število izletov, ki smo jih razvrstili v šest različnih zvrsti. Tako v kar 95 \% društev organizirajo izlete. Teh je v povprečju vsaj osem letno ali skupaj 1.848 izletov. Izmed vseh izletov, ki jih društva organizirajo, je največ tistih, ki trajajo ves dan (take organizirajo v 91,56 \% društev. Sledijo izleti, ki trajajo nekaj dni (46,67 \% društev). Poleg tega so morala društva svoje izlete razvrstiti še glede na lokacijo. Tukaj so imeli dve možnosti, in sicer Slovenija ali tujina. Med raziskovanimi društvi 
upokojencev prevladujejo izleti, ki so organizirani v Sloveniji $(94,71 \%$ društev organizira tovrstne izlete), v primerjavi z izleti, ki so organizirani v tujini $(45,81 \%)$. Ugotavljamo, da izleti, ki so organizirani po Sloveniji, skoraj nikoli ne trajajo več kot en dan. Društva, ki torej gredo na izlet po Sloveniji, na destinaciji ne prespijo. Izleti, ki so organizirani v tujini, pa običajno potekajo več dni.

Tabela 5. Distribucija glede na vrsto izletov

\begin{tabular}{l|rrrr}
\hline \multicolumn{1}{c|}{ Vrsta izleta } & $\begin{array}{c}\text { Stevilo društev, } \boldsymbol{k i} \\
\text { organizirajo izlete }\end{array}$ & $\begin{array}{c}\text { Delež med } \\
\text { vsemi } \\
\text { društvi }\end{array}$ & $\begin{array}{c}\text { Letno povprečje } \\
\text { organiziranih } \\
\text { izletov }\end{array}$ & $\begin{array}{c}\text { Vsi } \\
\text { organizirani } \\
\text { izleti v letu }\end{array}$ \\
\hline \multicolumn{1}{c|}{ SKUPAJ } & 216 & $95,58 \%$ & 8,24 & 1.848 \\
\hline 1 Dopoldanske / popoldanske & 42 & $19,53 \%$ & 1,31 & 293 \\
2 Dnevne & 206 & $91,56 \%$ & 6,05 & 1.361 \\
3 Večdnevne & 105 & $46,67 \%$ & 0,85 & 192 \\
4 Slovenija & 215 & $94,71 \%$ & 7,42 & 1.671 \\
5 Tujina & 104 & $45,81 \%$ & 0,76 & 171 \\
\hline
\end{tabular}

Iz ugotovitev lahko zaključimo, da imajo društva upokojencev v Sloveniji zelo razvito mrežo storitev za svoje člane, ki vključuje tako dneve in večdnevne izlete v Sloveniji in tujini.

Pri naslednjem vprašanju (Tabela 6), kako iščejo člani društva informacije pred potovanjem, smo anketirancem ponudili pet možnih trditev. Pri vsaki izmed trditev je bila na voljo lestvica od 1 do 5, pri čemer je anketiranec, ki je pri posamezni trditvi zapisal številko 1, izrazil popolno nestrinjanje, pri številki 5 pa popolno strinjanje s trditvijo. Kot lahko razberemo iz preglednice (Napaka! Neveljavno samosklicevanje zaznamka.), ni nobena izmed trditev prevladala ne v pozitivno ne v negativno smer. Še največji konsenz med društvi je bil pri zadnji trditvi $(3,24)$, da člani društva iščejo informacije preko znancev iste starostne skupine ali upoštevajo priporočila drugih društev. Omeniti še velja trditev, da člani društev iščejo informacije preko turistične agencije, ki jo najdemo v drugi vrstici $(3,08)$. Najmanj so se društva poistovetila s četrto trditvijo, da člani iščejo informacije za izlete v različnih katalogih $(2,64)$. Tako lahko zaključimo, da so člani društev upokojencev pri iskanju informacij še dokaj konzervativni.

Tabela 6. Trditve o iskanju informacij pred potovanjem

\begin{tabular}{l|ccc}
\hline Kako iščejo člani vašega društva informacije pred potovanjem? & $\begin{array}{c}\text { Skupaj } \\
\text { [n] }\end{array}$ & $\begin{array}{c}\text { Povprečje } \\
\text { Standardni } \\
\text { odklon }\end{array}$ \\
\hline 1 Člani našega društva iščejo informacije preko spleta. & 222 & 2,68 & 1,369 \\
2 Člani našega društva iščejo informacije preko turistične agencije. & 223 & 3,08 & 1,551 \\
3 Člani našega društva iščejo informacije preko katalogov. & 222 & 2,64 & 1,390 \\
4 Člani našega društva iščejo informacije preko družinskih članov. & 222 & 2,71 & 1,293 \\
5 Člani našega društva iščejo informacije preko znancev iste starostne & 222 & 3,24 & 1,399 \\
skupine ali priporočil drugih društev. & & & \\
\hline
\end{tabular}

Sledilo je vprašanje (Tabela 7), kjer nas je zanimalo, kako sta jim pri potovanjih pomembna transport in logistika, kar se nam je zdelo smiselno vključiti v raziskavo pri društvih upokojencev. Ugotovili smo, da je največ strinjanja bilo pri zadnji, četrti trditvi, v kateri je 
zapisano, da člani radi potujejo $\mathrm{v}$ organizirani skupini z vnaprej pripravljenim programom brez »presenečenj« na terenu $(4,13)$. Najmanj so se člani društev upokojencev strinjali z drugo trditvijo, torej, da jim je pomembno, da je program ločen za ljudi s posebnimi potrebami, saj je pri transportu to zelo velikega pomena $(2,53)$.

Tabela 7. Trditve o pomembnosti transporta in logistike na potovanjih

\begin{tabular}{c|ccc}
\hline Kako sta članom vašega društva pomembna transport in logistika? & $\begin{array}{c}\text { Skupaj } \\
\text { [n] }\end{array}$ & $\begin{array}{c}\text { Povprečje } \\
\text { Standardni } \\
\text { odklon }\end{array}$ \\
\hline $\begin{array}{c}\text { 1 Pomembno jim je, da osebje, s katerim potujejo, dobro pozna morebitne } \\
\text { težave ljudi s posebnimi potrebami. }\end{array}$ & 219 & 3,32 & 1,327 \\
2 Pomembno jim je, da je program ločen za ljudi s posebnimi potrebami, \\
$\begin{array}{c}\text { saj je pri transportu to zelo velikega pomena. } \\
\text { Pomembno jim je, da je na avtobusu omogočena ustrezna nujna } \\
\text { medicinska pomoč in prisotna oseba, ki zna reagirati v situacijah, ko je } \\
\text { potrebna medicinska pomoč. }\end{array}$ & 219 & 2,53 & 1,275 \\
$4 \begin{array}{c}\text { Clani radi potujejo v organizirani skupini z vnaprej pripravljenim } \\
\text { programom brez »presenečenj«na terenu. }\end{array}$ & 223 & 2,80 & 1,263 \\
\hline
\end{tabular}

Nadalje nas je zanimalo (Tabela 8), kako pomembna je za člane društva namestitev. Pripravili smo pet trditev, ki so jih, tako kot pri prejšnjih dveh vprašanjih, morali številčno označiti od 1 , če se s trditvijo popolnoma ne strinjajo, do 5, če se popolnoma strinjajo z dano trditvijo. Kaj smo ugotovili? Največ društev se je strinjalo, da pri izboru dopustovanja igra zelo veliko vlogo cena $(4,43)$. Najmanj strinjanja pa sta imeli trditvi, ki jih najdemo pod številkama 4 in 5 , torej, da člani želijo v nastanitvenem obratu zdraviliške oziroma velnes storitve pod številko $4(2,73)$ in da je članom pomembna klasifikacija nastanitvenega obrata pod številko $5(2,78)$. Ugotavljamo, da bodo upokojenci pri izbiri namestitvenega obrata bolj gledali na ceno kot pa na udobje.

Tabela 8. Trditve o pomembnosti namestitve za člane društev upokojencev

\begin{tabular}{|c|c|c|c|}
\hline Kako pomembna je za člane vašega društva namestitev? & $\begin{array}{l}\text { Skupaj } \\
\quad[n]\end{array}$ & Povprečje & $\begin{array}{l}\text { Standardni } \\
\text { odklon }\end{array}$ \\
\hline 1 Cena igra veliko vlogo pri izboru dopustovanja. & 225 & 4,43 & 1,132 \\
\hline $\begin{array}{l}2 \text { Zelo pomembno je, da je prehrana urejena } \mathrm{v} \text { nastanitvenem obratu in da } \\
\text { je prilagojena bolnikom } \mathrm{z} \text { dietami in/ali kroničnimi boleznimi. }\end{array}$ & 218 & 3,58 & 1,287 \\
\hline $\begin{array}{l}3 \text { Člani želijo imeti skupne namestitvene prostore (ne želijo biti razporejeni } \\
\text { po več objektih). }\end{array}$ & 220 & 3,33 & 1,366 \\
\hline 4 Člani želijo zdraviliške in/ali velnes storitve v nastanitvenem obratu. & 216 & 2,73 & 1,247 \\
\hline $\begin{array}{l}5 \text { Članom je pomembna klasifikacija nastanitvenega obrata (zvezdice, } \\
\text { jabolka, eko znaki, certifikati ...). }\end{array}$ & 219 & 2,78 & 1,195 \\
\hline
\end{tabular}

Tako lahko zaključimo da je članom društva upokojencev pri namestitvi pomembna cena, manj pa klasifikacija nastanitvenega obrata.

Pri zadnjem vprašanju (Tabela 9), v katerem smo spraševali o pomembnosti storitev na sami lokaciji in dostopnosti znamenitosti, smo anketirancem dali na izbiro pet trditev, pri katerih pa večjega odstopanja ni bilo. Same trditve imajo sicer malenkostno odstopanje navzgor (povprečje je je na lestvici od 1 do 5 večje od 3) vendar ne moremo zaključiti da bi jim bil 
kakšen element z izjemo »da se društvom zdi pomembno, da je dovolj obvestil o morebitnih nevšečnostih za turiste« $(3,95)$.

Tabela 9. Trditve o pomembnosti storitev in dostopnosti znamenitosti na sami lokaciji

\begin{tabular}{l|ccc}
\hline $\begin{array}{c}\text { Kako pomembna je storitev na sami lokaciji - dostopnost znamenitosti } \\
\text { (kulturna, zgodovinska, tehniška dediščina, naravne znamenitosti, }\end{array}$ & $\begin{array}{c}\text { Skupaj } \\
\text { [n] }\end{array}$ & $\begin{array}{c}\text { Povprečje } \\
\text { parki, muzeji ...) }\end{array}$ & $\begin{array}{c}\text { Standardni } \\
\text { odklon }\end{array}$ \\
\hline $\begin{array}{c}\text { 1 Pomembno jim je, da je omogočena dostopnost za ljudi s posebnimi } \\
\text { potrebami. }\end{array}$ & 219 & 3,42 & 1,357 \\
$\begin{array}{c}\text { 2 Pomembno jim je, da je prilagojeno vodenje za ljudi s posebnimi } \\
\text { potrebami. }\end{array}$ & 221 & 3,28 & 1,373 \\
3 Pomembno jim je, da so prilagojene vsebine za individualne obiske ljudi \\
$\begin{array}{c}\text { s posebnimi potrebami. } \\
\text { 4 Pomembno jim je, da so v primeru povpraševanja po dodatnih storitvah } \\
\text { za ljudi s posebnimi potrebami le-te omogočene. }\end{array}$ & 221 & 3,20 & 1,358 \\
$\begin{array}{c}\text { P Pomembno jim je, da je dovolj obvestil o morebitnih nevšečnostih za } \\
\text { turiste (npr. možnost zdrsa zaradi vlažne površine ...). }\end{array}$ & 222 & 3,31 & 1,299 \\
\hline
\end{tabular}

Iz rezultatov lahko ponovno zaključimo, da želijo biti člani društev upokojencev v naprej seznanjeni o poteku izletov in o tem, kaj jih lahko čaka na poti.

$\mathrm{Z}$ raziskavo smo želeli ugotoviti, kakšna je stopnja razvitosti in ponudba dostopnega turizma $\mathrm{v}$ društvih upokojencev ter ali se posebej znotraj društva prilagajajo določenim ciljnih skupinam ljudi, v našem primeru ljudi s posebnimi potrebami, in kako. Kaj smo ugotovili?

V kolikor odgovorimo na raziskovalno vprašanje, »kako pogosto in s kakšnimi motivi se upokojenci poslužujejo turističnih ponudb $\mathrm{v}$ okviru organiziranih prostočasnih aktivnosti društev upokojencev«, ugotavljamo:

Slovenska društva upokojencev imajo zelo razvito mrežo, ki je zastopana po vseh regijah, povprečna starost članov slovenskih društev relativno nizka $(73,4$ let), in da se bo v prihodnjih letih samo še dvigovala. Svojim članom ponujajo svojim članom veliko število prostočasnih aktivnosti in turističnih potovanj. Največ ponujajo izlete, potovanja, oglede muzejev in ogled znamenitosti kot tudi praznovanja ipd. Tako v kar $95 \%$ društev organizirajo izlete. Teh je v povprečju vsaj osem letno. Izmed vseh izletov, ki jih društva organizirajo, je največ tistih, ki trajajo ves dan (take organizirajo v 91,56 \% društev). Sledijo izleti, ki trajajo nekaj dni (46,67 \% društev). Poleg tega so morala društva svoje izlete razvrstiti še glede na lokacijo. Tukaj so imeli dve možnosti, in sicer Slovenija ali tujina. Med raziskovanimi društvi upokojencev prevladujejo izleti, ki so organizirani v Sloveniji (94,71 \% društev organizira tovrstne izlete), v primerjavi $\mathrm{z}$ izleti, ki so organizirani $\mathrm{v}$ tujini $(45,81 \%)$. Ugotavljamo, da izleti, ki so organizirani po Sloveniji, skoraj nikoli ne trajajo več kot en dan. Torej, društva, ki gredo na izlet po Sloveniji, na destinaciji ne prespijo. Izleti, ki so organizirani v tujini, pa običajno potekajo več dni.

Pri iskanju informacij pred turističnim potovanjem še dokaj konzervativni in zaupajo znancem iste starostne skupine ali priporočilo drugih društev oz. se o ponudbi prepričajo pri turistični 
agenciji osebno. Poleg tega radi potujejo $\mathrm{v}$ organizirani skupini $\mathrm{z}$ vnaprej pripravljenim programom brez »presenečenj« na terenu. Pri namestitvi je pomembna cena, manj pa klasifikacija nastanitvenega obrata, poleg tega pa želijo biti v naprej seznanjeni o poteku izletov in o tem, kaj jih čaka na poti. Zaključimo lahko s trditvijo, da je slovenskim društvom upokojencev veliko bolj kot udobje pomembna cena izleta.

\section{Zaključek}

Društva upokojencev imajo organiziranih veliko prostočasnih dejavnosti. Pri turističnih potovanjih se bolj nagibajo k dnevnim izletom po Slovenji. Zaradi omejenih financ je pri odločitvi za izbiro gostinskega obrata pomembna cena namestitve, veliko manj pa je upokojence zanimalo, kakšna je klasifikacija namestitve.

Ugotovitve raziskave so relevantne za turistične organizacije in društva upokojencev. Tako lahko turistične organizacije prilagodijo turistično ponudbo. Društva upokojencev se pri organizaciji prostočasnih dejavnosti lahko povežejo in optimizirajo delo.

Prispevek je pomemben z vidika starajoče se družbe. Delež starejših oseb se namreč povečuje in bo potrebno ustrezno poskrbeti tudi za njihove prostočasne aktivnosti, kamor sodijo tudi turistične dejavnosti.

Raziskava je pokazala, da so slovenska društva upokojencev izrazito nagnjena $\mathrm{k}$ nizkocenovnemu enodnevnemu turizmu, ki je bolj ali manj lociran v Sloveniji. Glede programa izletov si želijo biti predhodno obveščeni. Zaželeno je, da izleti potekajo po ustavljenem urniku brez kakšnih večjih presenečenj, ki bi lahko zahtevale dodatno plačilo. To pa je glede na finančno stanje upokojencev dokaj razumljivo in pričakovati je, da bo tako tudi v bodoče. Kje so torej rešitve? Zagotovo v večji medgeneracijski solidarnosti, dejavnosti društev v okviru prostočasnih dejavnosti na lokalnem nivoju in posluževanja koriščenja turističnih potovanj $\mathrm{v}$ mrtvi sezoni, ko so cene praviloma nižje. Ponudniki turistični ponudniki pa bi se morali prilagoditi temu segmentu in oblikovati upokojencem »na kožo pisane« pakete.

Omejitev raziskave se kaže v tem, da so bili vključeni le vodje društev upokojencev. Za celovito mnenje bi morali izvesti fokusne skupine v nekaj izbranih društvih upokojencev in po mnenju povprašati tudi člane neposredno. Raziskava tudi ne pokriva upokojencev, ki niso aktivni v društvih.

\section{Reference}

1. Avcikurt, C. (2009). The mature age market in Europe \& its influence on tourism. Tourism Rewiev H.

2. Beer, D. (2013). Europe: one continent, different worlds: population scenarios for the 21 st century (Let. 7). Springer Science \& Business Media.

3. Börsch-Supan, A. (2018). Survey of Health, Ageing and Retirement in Europe (SHARE) Wave 4. Release version: 6.1.1. https://doi.org/DOI: 10.6103/SHARE.w4.611.

4. Dann, G. M. S. (2001). Senior tourism. Annals of Tourism Research, 28(1), 235-238. 
5. Dobrina, A. (2017). Demografske spremembe in gmotni položaj upokojencev v Republiki Sloveniji. Javno zdravje, 1(1), 9-14.

6. Europe Senior Tourism. (2017). Pridobljeno 10. december 2017 s spletne strani http://www.europeseniortourism.eu/en/index.html.

7. Evropska komisija. (2018). Tematski informativni pregled v okviru evropskega semestra: Pridobljeno 16. 07. 2018 s spletne strani https://ec.europa.eu/info/sites/info/files/file_import/european-semester_thematicfactsheet_adequacy-sustainability-pensions_sl.pdf

8. Gliha Komac, N. (2017). Slovar slovenskega knjižnega jezika 2016. Ljubljana: ZRC SAZU. Pridobljeno dne 25. 12. 2018 s spletne strani https://isjfr. zrc-sazu. si/sites/default ...

9. Goriup, J. (2014). Vpliv globalizacije na družbo znanja in medgeneracijsko učenje. Revija za ekonomske in poslovne vede, 1(1), 83-101.

10. Hojnik-Zupanc, I., \& Mlinar, Z. (1999). Samostojnost starega človeka v družbeno-prostorskem kontekstu. Fakulteta za družbene vede.

11. Hren, R., Prevolnik Rupel, V., \& Srakar, A. (2015). Analiza uporabe zdravstvenih storitev pri starejših Slovencih : prvi rezultati 4. vala raziskave SHARE. Značilnosti starejšega prebivalstva $v$ Sloveniji - prvi rezultati raziskave SHARE, 75-82.

12. Krašovec, K. (2003). Seniorji v turizmu. Diplomska naloga. Portoroz: [K. Krasovec].

13. Lavrič, M., \& Godina, V. V. (2011). Mladina 2010: Družbeni profil mladih v Sloveniji. Ministrstvo za šolstvo in šport, Urad RS za mladino.

14. Litrell, M. A., Paige, R. C., \& Sung, K. (2004). Senior travellers: Tourism activities and shopping behaviours. Journal of Vacation Marketing, 10(4), 348-362.

15. Malnar, S. (2015). Socialna opora članov društva upokojencev Ribnica. Ljubljana: Univerza v Ljubljani, Fakulteta za druzbene vede.

16. Pogačnik, A., Leskovec, B., Cigale, D., Prosen, A., in Laharnar, B. (2008). Prostorsko načrtovanje turizma. Ljubljana: Fakulteta za gradbeništvo in geodezijo, Komisija za tisk.

17. Population and social conditions - Statistics Explained. (2017). Pridobljeno 10. december 2017s spletne strani http://ec.europa.eu/eurostat/statisticsexplained/index.php/Population_and_social_conditions.

18. Ramov̌̌, J. (2003). Kakovostna starost: socialna gerontologija in gerontagogika. Ljubljana: Inštitut Antona Trstenjaka in Slovenska akademija znanosti in umetnosti.

19. Ramovš, J. (2014). Staranje in sožitje med generacijami v Občini Ivančna Gorica. Kakovostna starost, 17(3).

20. Raspor, A., Šumer, A., Macuh, B., Guštin, G., Ivanovska, J., Gregorčič, A., ... Raspor, S. (2018). Postavitev izhodišč za razvoj turizma za starejše in gibalno ovirane osebe. Dolga Poljana: Perfectus, Svetovanje in izobrazevanje. Pridobljeno dne 20. 09. $2018 \mathrm{~s}$ spletne strani http://www.andrejraspor.com/perfectus_zalozba

21. Thompson, D. (2016). The Invisible Revolution: How Aging Is Quietly Changing America. The Atlantic.

22. Weiermair, K., \& Mathies, C. (2004). The Tourism and Leisure Industry: Shaping the Future. Binghampton, NY: Haworth Press.

23. Zavod za pokojninsko in invalidsko zavarovanje Slovenije. (2017). Letno poročilo 2016. Ljubljana: Zavod za pokojninsko in invalidsko zavarovanje Slovenije.

24. Zavod za pokojninsko in invalidsko zavarovanje Slovenije. (2019). Mesečni statistični pregled November 2019. Pridobljeno 5. januar 2020 s spletne strani https://www.zpiz.si/cms/content2019/21meseni-statistini-pregled-november-2019.

Doc. dr. Bojan Macuh je prof. soc. in slov. Doktorski študij je zaključil na Pedagoški fakulteti Univerze na Primorskem, pred tem pa magistrski študij sociologije na Filozofski fakulteti Univerze v Mariboru. Od leta 2009 je predavatelj na Fakulteti za poslovne in komercialne vede v Celju, kjer predava sociologijo. Na Gea College v Ljubljani občasno predava od leta 2013 poslovno etiko in organizacijsko kulturo. Na Višji šoli za kozmetiko in velnes predava predmet čustvena inteligenca in osebnostni razvoj. Je avtor in soavtor znanstvenih in strokovnih 
monografij, priročnikov ter več znanstvenih, strokovnih in poljudnih člankov. S svojimi prispevki kot avtor in soavtor je sodeloval na več mednarodnih znanstvenih konferencah. Hkrati je avtor tudi več leposlovnih del za odrasle, mladino in otroke.

Izr. prof. dr. Andrej Raspor je po osnovni izobrazbi strojni tehnik, uni. dipl. organizator dela in doktor družbenih - upravljavskih ved. Pri svojem delu združuje poslovno in akademsko delo. Predava in svetuje s področja organizacije dela, prenove poslovnih procesov, turizma in igralništva, kakovosti storitev ter razvoja kadrov. Ima več kot 32 let delovnih izkušenj, od tega več kot 17 let na različnih vodilnih mestih. Preden se je zaposlil kot direktor v lastnem podjetju, je bil vodja splošnih poslov, vodja komisije za nadzor stroškov, direktor razvoja kadrov in direktor strateških projektov. Vodil prenovo poslovnih procesov razvoja kadrov in trženja ter organiziral poslovanje za kitajske goste z območja Italije in Kitajske. Je podjetnik, ustanovitelj več start-upov, poslovni svetovalec in mentor. Sodeloval je na številnih mednarodnih konferencah, objavil izsledke svojih raziskav v znanstvenih revijah z recenzentskim postopkom. Je avtor več znanstvenih in strokovnih monografij ter uporabnih priročnikov iz področja kakovosti storitve, turizma in igralništva.

\section{Abstract: \\ Societies of Pensioners as Promotors of Tourist Consumption and Leisure Activities of Slovenian Pensioners}

Research question: How frequently pensioners use tourist offers as part of organised leisure activities of societies of pensioners, and what are their motifs for this?

Aim: We want to find out, how are organised leisure activities and whether exist enough tourist offers for pensioners with regard to their financial situation and obstacles they face.

Methods: We conducted research among Slovenian societies of pensioners. We conducted online survey which took place from 15 April to 15 July 2018. To increase responsiveness which was very low in the first stage of the survey, we added phone survey which was conducted by students of the School of advanced social studies.

Results: Societies of pensioners organise many leisure activities. In a segment of tourist trips they prefer day trips around Slovenian. Due to limited finances a crucial factor in choosing accomodation is its price, while pensioners put much less attention on the classification of accomodation.

Organisation: Findings of the research are relevant for tourist organisations and societies of pensioners. They enable tourist organisations to adapt their offers. Societies of pensioners have an option to co-operate in organising leisure activities and optimise their work.

Society: Our contribution is important from a perspective of ageing society. Namely, a share of older persons increases, what evokes a need to manage also their leisure activities which include also tourist activities.

Originality: It is the first so comprehensive survey conducted among Slovenian societies of pensioners which looked for answers with regard to organising tourist trips and motifs of pensioners to participate in them.

Limitations of research: Limitation of research is reflected in a fact, that it included only heads of societies of pensioners. For a comprehensive view we should form some focus groups in selected societies of pensioners, as well as directly ask their members for their opinions. Furthermore, the research does not cover pensioners who are not active in societies.

Keywords: Slovenia, pensioners, tourism, destination, trips, offer. 
Revija za univerzalno odličnost / Journal of Universal Excellence,

Članek / Article

Marec / March 2020, leto / year 9, številka / number 1, str. / pp. 16-30. 